\title{
Spatial and temporal variability of canopy cover and understory light in a Cerrado of Southern Brazil
}

\author{
Lemos-Filho, JP. ${ }^{\mathrm{a} *}$, Barros, CFA. ${ }^{\mathrm{b}}$, Dantas, GPM. ${ }^{\mathrm{b}}$, Dias, $L G .^{\mathrm{b}}$ and Mendes, $R S .{ }^{\mathrm{b}}$ \\ ${ }^{\text {a } D e p a r t a m e n t o ~ d e ~ B o t a ̂ n i c a ~-~ I n s t i t u t o ~ d e ~ C i e ̂ n c i a s ~ B i o l o ́ g i c a s ~-~ I C B, ~}$ \\ Universidade Federal de Minas Gerais - UMFG, \\ CEP 31270-901, Belo Horizonte, MG, Brazil

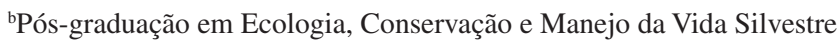 \\ Universidade Federal de Minas Gerais - UMFG, \\ CEP 31270-901, Belo Horizonte, MG, Brazil \\ *e-mail: lemos@icb.ufmg.br
}

Received July 14, 2009 - Accepted September 30, 2008 - Distributed February 28, 2010

(With 3 figures)

\begin{abstract}
Canopy cover has significant effects on the understory environment, including upon light availability for seedling growth. The aim of the present study was to verify spatial heterogeneity and seasonal changes in the canopy cover of a dense Cerrado area, and their relationship to understory photosynthetic active radiation availability. Leaf area index (LAI) values in the rainy season varied from 0.9 to 4.83 , with $40 \%$ of the values ranging from 4.0 to 5.0 , while in the dry season LAI varied from 0.74 to 3.3 , with $53 \%$ of the values oscilating from 2.0 to 3.0. Understory light $\left(\mathrm{Q}_{\mathrm{i}}\right)$ and the Lambert-Beer ratio $\left(\mathrm{Q}_{i} / \mathrm{Q}_{0}\right)$ were taken around noon on sunny days (between 11:00 AM and 1:00 PM). They were also statistically different $(\mathrm{p}<0.01)$ between the dry and wet seasons, with $72 \%$ of sampled points in the rainy season presenting photosynthetic photon flux density (PPFD) values lower than $250 \mu \mathrm{mol} . \mathrm{m}^{-2} / \mathrm{s}$ around noon, whereas in the dry season, most PPFD values varied from 1500 to $1817 \mu \mathrm{mol} . \mathrm{m}^{-2} / \mathrm{s}$, thus providing high light availability for understory plants. In most of the studied sites, understory plants did not even receive enough light for $50 \%$ of their photosynthetic capacity in the wet season. In contrast during the dry season, $\mathrm{Q}_{\mathrm{i}} / \mathrm{Q}_{\mathrm{o}}$ values of 0.8 to 1.0 were observed in more than $50 \%$ of the points, thereby allowing for photosynthetic light saturation. Thus, light variability around noon was higher during the dry season than in the wet season, its heterogeneity being related to spatial complexity in the canopy cover
\end{abstract}

Keywords: leaf area index, Lambert-Beer ratio, photosynthesis, seedling growth, tropical savanna.

\section{Variabilidade espacial e temporal da cobertura do dossel e da luz no sub-bosque em uma área de Cerrado no Sudeste do Brasil}

\begin{abstract}
Resumo
A cobertura do dossel tem efeitos significativos no ambiente do sub-bosque incluindo a disponibilidade de luz para o crescimento das plântulas. O objetivo do presente estudo foi verificar a heterogeneidade espacial e as mudanças sazonais da cobertura do dossel em uma area de Cerrado denso e sua relação com a radiação fotossintetica ativa diponivel no sub-bosque. Os valores do índice de área foliar (IAF) na estação chuvosa variaram de 0,9 a 4,83 com $40 \%$ dos valores dentro de 4,0 a 5,0, enquanto na estação seca o IAF variou de 0,74 a 3,3 com 53\% dos valores dentro de 2,0 a 3,0. A luz abaixo do dossel (Qi) e razão de Lambert-Beer (Qi/Qo) foi obtida entre as 11:00 e 13:00 horas em dias ensolarados. Os valores também foram estatisticamente diferentes $(p<0.01)$ entre a estação seca e a chuvosa, com $72 \%$ dos pontos amostrados na estação chuvosa apresentando valores de densidade de fluxo de fotons fotossinteticamente ativos (DFFA) menores de $250 \mu \mathrm{mol} . \mathrm{m}^{-2} / \mathrm{s}$ por volta do meio dia, enquanto na estação seca a maioria dos valores de DFFA variou entre 1500 a $1817 \mu \mathrm{mol} . \mathrm{m}^{-2} / \mathrm{s}$ propiciando alta disponibilidade de luz para o sub-bosque. Na maior parte dos pontos amostrados, as plantas de sub-bosque não receberam quantidade de luz suficiente para $50 \%$ de sua capacidade fotossintetica na estação chuvosa. Em contraste durante a estação seca foram observados valores de of Qi/Qo de 0.8 a 1.0 em mais de $50 \%$ dos pontos amostrados, permitindo a saturação de luz da fotossíntese. A variabilidade de luz por volta do meio dia no sub-bosque foi maior durante a estação seca do que na estação chuvosa, e a heterogeneidade foi relacionada com a complexidade espacial da cobertura do dossel.
\end{abstract}

Palavras-chave: índice de área foliar, razão Lambert-beer, fotossíntese, crescimento de plântulas, savana tropical. 


\section{Introduction}

Leaf area index (LAI), defined as the ratio of total leaf area per unit of ground cover, is considered as an important parameter in climatic and ecosystem models (White et al., 2000). Because of its important influence in the exchange of energy, water-vapour and carbon dioxide between terrestrial ecosystems and the atmosphere, most of the models that simulate carbon and hydrologic cycles require LAI as an input variable (Gower et al., 1999).

LAI is also related to understory light availability, since the penetration of direct beam radiation through the canopy is influenced by several characteristics, particularly the height and cover of overstory plants. The position, angle, and spatial relationships of canopy elements affect the passage of solar radiation through the canopy (Gower et al., 1999). Physical damage to leaves and branches, herbivory or disease, diurnal and seasonal changes in the sun's angle and plant phenology, all result in canopy heterogeneity (Wirth et al., 2001). These canopy changes have a significant impact on the understory environment, due to their effect on the microclimate (e.g. light, soil and leaf temperature and soil evaporation), which also varies within different canopy patches (Martens et al., 2000).

The Brazilian Cerrado is a floristic province that presents diverse physiognomic forms, varying from closed forest-like arrangements, through arboreal woodlands, tree and scrub woodlands, and closed or openscrub savannas to pure grasslands (Eiten, 1972). The vegetation is composed of evergreen and deciduous woody plants and grasses with relatively shallow roots, growing in oligotrophic soils and subject to frequent fires (Bucci et al., 2005). The climate is similar to many of the wetter savanna regions of the world, with a very rigorous dry season during the southern winter. The average annual rainfall is $800-2000 \mathrm{~mm}$, with an average annual temperature between 18 and $28^{\circ} \mathrm{C}$ (Ratter et al., 1997; 2006).

In spite of the importance of the leaf area index (LAI) as a determinant factor in ecological and biophysical processes in terrestrial ecosystems, there are few studies with LAI in savanna areas world-wide, especially in the Neotropics. In the West African humid savanna, Le Roux and Mordelet (1995) showed that seasonal variation of the canopy $\mathrm{CO}_{2}$ assimilation rate is dependent on LAI variation. O Grady et al. (2000) described seasonal variation in overstory LAI due to the greater contribution of deciduous and semi-deciduous species of Eucalypt in the Australian open-forest savanna. In the Brazilian Cerrado, Miranda et al. (1997) also described seasonal changes in LAI and pointed out a reduction of about $35 \%$ in ecosystem photosynthetic rates simply due to the lower LAI in the dry season. In a recent study, Bucci et al (2008) showed that transpiration increases with LAI in all Cerrado studied physiognomies in both the dry and wet seasons. Also recently, Silva et al. (2008) observed that the differential LAI values of wood species and grass in a transect between a gallery forest and Cerrado were highly correlated with $\delta^{13} \mathrm{C}$ values of the soil organic carbon. They showed an increase of $\delta^{13} \mathrm{C}$ with the increase of grass LAI values and a decrease with the increase of LAI from woody species. Considering the importance of LAI to understanding several ecological processes, we reported herein our studies concerning seasonal changes of LAI in a dense Cerrado. We also presented the relationships between canopy heterogeneity and understory light. In addition, these results were interpreted in relation to available light for seedling growth, considering the photosynthetic light curve responses of Cerrado species.

\section{Materials and Methods}

This study was carried out in the Serra do Cipó National Park (19 $19^{\prime}$ - $19^{\circ} 30^{\prime} \mathrm{S}$ and $\left.43^{\circ} 28^{\prime}-43^{\circ} 40^{\prime} \mathrm{W}\right)$, Minas Gerais State, Brazil. Several savanna physiognomies are to be found in this protected area, including the Cerrado senso stricto. The climate is highly seasonal, with a mean annual rainfall of $1600 \mathrm{~mm}$. Beginning in May, there are five months of drought with a mean total rainfall lower than $40 \mathrm{~mm}$. The wet season starts at the end of September (Marques et al., 2000).

The study site is located in an area with quartizitic dystrophic soil, and presents a predominance of characteristic Cerrado trees, which reach a height of from 3 to $5 \mathrm{~m}$, and include such species as Stryphnodendron adstringens, Qualea grandiflora, Q. parviflora, Plathymenia reticulata, and Hymenea Stygonocarpa. A diversified poaceae stratum predominates at ground level, with the occurrence of spaced-scrubs.

Measurements of the leaf area index (LAI) and photosynthetic photon flux density (PPFD) were taken at the end of both the dry season (September 2001) and the rainy season (April 2002), on a grid of four $30 \mathrm{~m}$ parallel transects (120 m long), oriented to an azimutal angle of $120^{\circ}$. Eight $15 \mathrm{~m}$-spaced points were located in each transect, where LAI and PPFD measurements were taken, altogether a total sampled area of $14,400 \mathrm{~m}^{2}$. The distance from the nearest individual tree in each quadrant at each sampling point and the girth at breast-height $(\mathrm{GBH})$ were registered by using the point-centered quarter method. For this procedure, only trees with a GBH of more than $0.10 \mathrm{~m}$ were considered.

LAI was estimated with a LAI-2000 Plant Canopy Analyser (Li-Cor, USA). This optical instrument, as described by Welles and Norman (1991), measures the canopy gap or fraction of sky over a range of zenith angles, thus providing indirect LAI values through the proportion of open-sky visible above the sample. By using multiple understory measurements, gap fractions are converted into LAI. Measurements were taken during early morning periods. For each of the 32 located points, the mean value was obtained from one full light measurement in clearings, immediately followed by that of six below-tree canopies (above the herbaceous layer), together with the sam- 
pling of all quadrants with overlaps, by using a $90^{\circ}$ lens cap $\left(270^{\circ}\right.$ occluded). Collected data corresponded to the vegetation area index (VAI), which is the projected area of all canopy components including woody parts (stem area index SAI). However, considering that in fully leaved canopies, VAI is very close to LAI (Dufrêne and Bréda, 1995), we hereafter used LAI instead of VAI.

Light measurements in an open environment and below tree/scrub canopy at each point were performed with a leveled LI-190SB (Li-Cor, USA) quantum sensor installed above the herbaceous layer $(\sim 1.2 \mathrm{~m})$ in order to determine the Beer-Lambert ratio $Q_{i} / Q_{o}$ where $Q_{i}$ is sub-canopy diffuse and beam radiation and $\mathrm{Q}_{0}$ is abovecanopy radiation. Instantaneous measurements of photosynthetic photon flux density (PPFD) were taken around noon on sunny days (between 11:00 AM and 1:00 PM) (Gendron et al., 1998), in order to avoid excessive variation in the sun's angle. Sub- and above-canopy measurements were taken within short time intervals $(0.5$ to 2 minutes) at each point. The Wilcoxon-paired-sample test was applied to assess seasonal differences while the Spearman correlation coefficient was used to test for relationships between the studied variables.

\section{Results}

For the Cerrado area studied, the distance from the nearest individual tree recorded by using the point- centred quarter method, varied from 1.25 to $4.43 \mathrm{~m}$ (an average of $3.20 \pm 0.79 \mathrm{~m}$ ) and the girth at breastheight $(\mathrm{GBH})$ between 0.23 and $0.77 \mathrm{~m}$ (an average of $0.43 \pm 0.13 \mathrm{~m}$ ), with a density of 1243 plant ha $\mathrm{h}^{-1}$ and basal area of $18.2 \mathrm{~m}^{2} \cdot \mathrm{ha}^{-1}$.

The values of visible sky fraction (VSF) and leaf area index (LAI) were statistically different between dry and wet season measurements (Table 1). High canopy cover heterogeneity between sampled points was observed in both seasons. In the dry season, VSF values varied from 6.9 to $53 \%$ and in the wet season from 2.3 to $46 \%$. This high canopy heterogeneity was also observed in relation to LAI values, which varied from 0.74 to 3.30 in the dry season and 0.91 to 4.83 in the wet season. However in $53 \%$ of the points sampled during the dry season, LAI values varied from 2.0 to 3.0 , whereas in the wet season, $40 \%$ of LAI values were observed to oscillate from 4.0 to 5.0 (Figure 1).

PPFD measured under trees and scrubs $\left(Q_{i}\right)$ was also statistically different $(p<0.01)$ between the dry and wet seasons (Table 1), this varying from 31 to $1817 \mu \mathrm{mol} . \mathrm{m}^{2} / \mathrm{s}$ within sampled points in September (end of the dry season), and from 10 to $1662 \mu \mathrm{mol} . \mathrm{m}^{-2} / \mathrm{s}$ in April (end of the wet season). The average of Qi values registered in April corresponds to $30 \%$ of the mean $\mathrm{Q}_{\mathrm{i}}$ observed in September. However, lower understory light heterogeneity was found during the wet season, since $72 \%$ of the sampled points presented $\mathrm{Q}_{\mathrm{i}}$ values lower

Table 1. Seasonal changes in visible sky fraction (VSF), leaf area index (LAI), under-canopy PPFD (Q), the Beer- Lambert ratio $\left(\mathrm{Q}_{\mathrm{i}} / \mathrm{Q}_{\mathrm{o}}\right)$ and the results of the Wilcoxon test, for 32 sampled points in a Cerrado patch in the dry and wet seasons. Data expressed as mean \pm standard deviation.

\begin{tabular}{lcccc}
\hline \multicolumn{1}{c}{ Variable } & Dry season & Wet season & $\mathbf{Z}$ & $\mathbf{P}$ \\
\hline VSF & $0.229 \pm 0.127$ & $0.120 \pm 0.111$ & 2.936 & 0.003 \\
LAI & $2.06 \pm 0.70$ & $3.28 \pm 1.13$ & 3.833 & 0.001 \\
$\mathrm{Q}_{\mathrm{i}}\left(\mu \mathrm{mol} . \mathrm{m}^{-2} / \mathrm{s}\right)$ & $1051 \pm 680$ & $316 \pm 453$ & 4.488 & 0.000 \\
$\mathrm{Q}_{\mathrm{i}} / \mathrm{Q}_{\mathrm{o}}$ & $0.679 \pm 0.321$ & $0.191 \pm 0.277$ & 4.918 & 0.000 \\
\hline
\end{tabular}

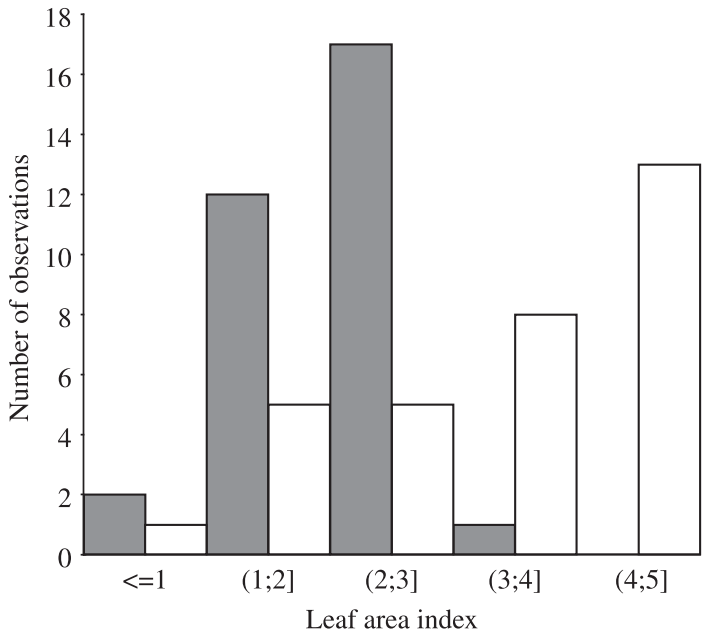

Figure 1. Frequency distribution of the canopy leaf area index (LAI) (trees plus scrubs) of a Cerrado area in dry (solid bars) and wet (open bars) seasons.

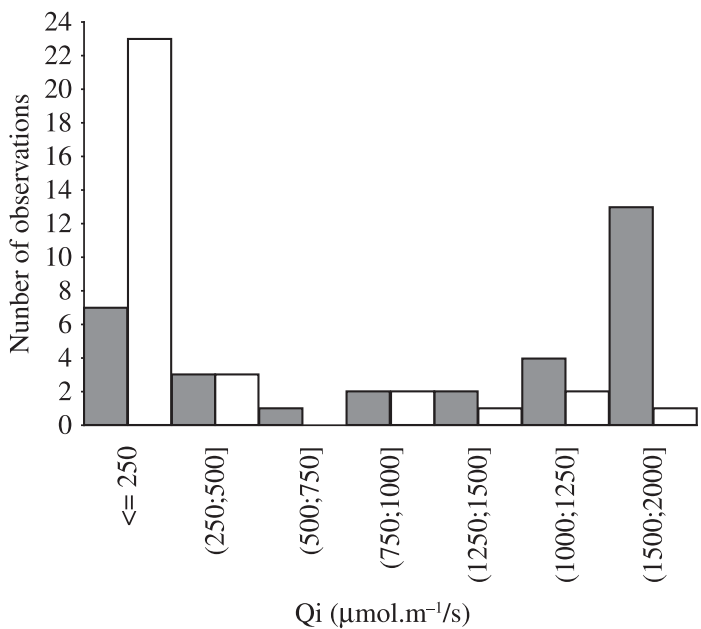

Figure 2. Frequency distribution of under-canopy PPFD (Qi) of a Cerrado area in dry (solid bars) and wet (open bars) seasons. 


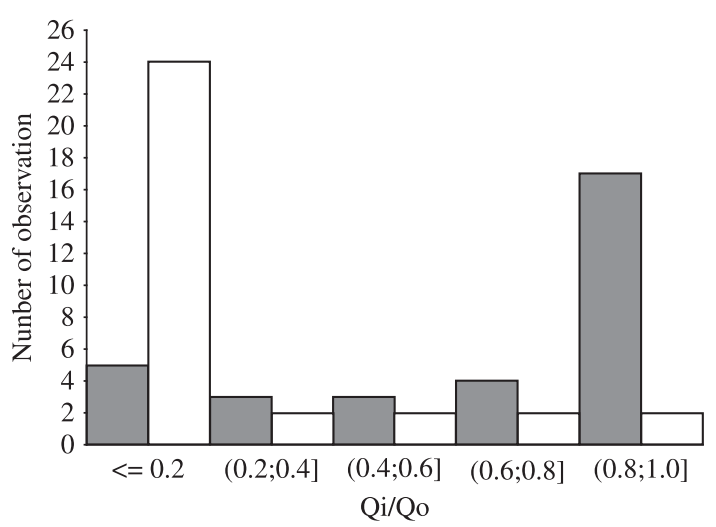

Figure 3. Frequency distribution of the under-canopy Lambert-Beer ratio (Qi/Qo) of a Cerrado area in dry (solid bars) and wet (open bars) seasons.

Table 2. Spearman correlation coefficients between the variables, visible sky fraction (VSF), leaf area index (LAI), under-canopy photosynthetic active radiation $\left(\mathrm{Q}_{\mathrm{i}}\right)$ and the Beer Lambert ratio $\left(\mathrm{Q}_{\mathrm{i}} / \mathrm{Q}_{\mathrm{o}}\right)$, recorded in the dry season, in relation to the same variables measured in the wet season, in a Cerrado patch. Correlations in bold type are statistically significant at $\mathrm{P}<0.05$. Underlined correlations are significant at $\mathrm{P}<0.01$.

\begin{tabular}{ccrccc}
\hline \multicolumn{7}{c}{ Wet season } \\
\hline \multirow{4}{*}{ Dry } & Variable & \multicolumn{1}{c}{ VSF } & \multicolumn{1}{c}{ LAI } & \multicolumn{1}{c}{$\mathbf{Q}_{\mathbf{i}}$} & $\mathbf{Q}_{\mathbf{i}} / \mathbf{Q}_{\mathbf{0}}$ \\
\cline { 2 - 6 } season & VSF & -0.0961 & -0.0278 & $\mathbf{0 . 4 2 0 2}$ & $\mathbf{0 . 4 2 3 9}$ \\
& LAI & 0.1063 & -0.0094 & $\mathbf{- 0 . 3 9 1 6}$ & $-\mathbf{0 . 3 9 3 3}$ \\
& $Q^{i}$ & -0.1511 & -0.2970 & $\underline{0.6294}$ & $\underline{0.6312}$ \\
& $\mathrm{Q}_{\mathrm{i}} / \mathrm{Q}_{0}$ & -0.1433 & -0.0337 & $\underline{0.6275}$ & $\underline{0.6298}$ \\
\hline
\end{tabular}

than $250 \mu$ mol. $\mathrm{m}^{-2} / \mathrm{s}$ (Figure 2). In the dry season, $40 \%$ of $\mathrm{Q}_{\mathrm{i}}$ values varied from 1500 to $1817 \mu \mathrm{mol} . \mathrm{m}^{-2} / \mathrm{s}$, thus propitiating high light availability for understory plants. As a result of increased canopy cover, Beer-Lambert ratio $\left(\mathrm{Q}_{\mathrm{i}} / \mathrm{Q}_{\mathrm{o}}\right)$ values significantly decreased from the dry to the wet seasons (Table 1), with 24 in 32 sampled points revealing values lower than $20 \%$ of total above-canopy light in the wet season, as against 17 in 32 sampled points showing $Q_{i} / Q_{0}$ values between 0.8 and 1.0 in the dry season (Figure 3). Despite these seasonal changes in canopy-cover, no significant relationship between all those variables measured during the dry season with VSF and LAI values observed in the wet season was found, although significant weak Spearman correlations VSF and LAI in the dry season with bellow canopy $\operatorname{PPFD}\left(\mathrm{Q}_{\mathrm{i}}\right)$ and $Q_{i} / Q_{0}$ were registered in the wet season. As expected, a somewhat better correlation existed between $\mathrm{Q}_{\mathrm{i}(\mathrm{dry})} \times$ $\mathrm{Q}_{\mathrm{i} \text { (wet) }}$ and $\mathrm{Q}_{\mathrm{i}} / \mathrm{Q}_{\mathrm{o} \text { (dry) }} \times \mathrm{Q}_{\mathrm{i}} / \mathrm{Q}_{\text {o(wet) }}$ (Table 2). These data suggest that the increase in LAI and decrease in VSF values during the wet season do not present any relationship with those observed in the dry season. However, $Q_{i}$ and $\mathrm{Q}_{\mathrm{i}} / \mathrm{Q}_{\mathrm{o}}$ measured during the wet season were related to both light and canopy characteristics observed in the dry season.

\section{Discussion}

Leaf area index (LAI) values observed during both the dry $(2.06 \pm 0.70)$ and wet $(3.28 \pm 1.13)$ seasons were, as expected, lower than those obtained for most tropical forests, with averages of roughly $6.2(\mathrm{SD}=1.5)$ (Wirt et al., 2001). However, mean LAI values obtained herein were higher than those from data described for other tropical savanna areas. For a Eucalypt savanna in Australia, Hutley (2000) stated that LAI values were typically 1.0 in the wet season and 0.65 in the dry. Even for a Cerrado in central Brazil, Miranda et al. (1997) obtained LAI values of 1.0 in the wet and 0.4 in the dry seasons, when considering only a mixture of leaves from shrubs, trees and grass. Values recorded in the Serra do Cipó National Park are may be a little high, because indirectly estimated LAI based on gap-fraction analysis included the projected stem and branch area. However, the obtained LAI values were not so different from the values described by Asner (1998) for 30 common species of Cerrado, these ranging from 3.1 to 5.9. Even when subtracting the highest stem area index (SAI) value of 0.7 for Cerrado trees (Asner, 1998), obtained values remained higher than those described by Miranda et al. (1997). In another study in five Cerrado sites, Hoffmann et al. (2005) found that LAI values ranged from 2.48 in the "cerradão" to 0.28 in the "campo sujo". They also estimated that the stem area index (SAI) corresponded to $13.9 \%$ of the vegetation area index (VAI). On considering these SAI values, the new re-calculated LAI mean value of 2.83 for the wet season in the present study is close to that described for denser Cerrado vegetation.

VSF and LAI canopy structural parameters presented no relationship between wet and dry seasons. This could be interpreted as a result of differential species phenological behaviour, plus architectural complexity of Cerrado vegetation (expressed as wood/leaf ratio). This complexity results in high canopy cover spatial variability between the dry and wet seasons. In a study on canopy structure in a tropical forest on Barro Colorado Island, Panamá, Wirth et al. (2001) also observed high temporal variability in LAI values. They concluded that canopy-level means for structural parameters may not be sufficient to adequately describe functional changes in canopy structure, since areas of sampled plots did not present changes in LAI due to the presence of evergreen trees, whereas other plots presented appreciable changes because of deciduous trees.

As expected for more open environments, $Q_{i} / Q_{0}$ values obtained for the Serra do Cipó Cerrado were higher in relation to wet forests, mainly during the dry season. An examination of $Q_{i} / Q_{0}$ frequency distribution in various Costa Rican wet forests (Nicotra et al., 1999) showed that in old-growth stands, $33-50 \%$ of the micro-sites received $<1 \%$ of full sunlight compared to $11-36 \%$ of 
those in secondary growth stands. In a tropical deciduous forest in Mexico, Maass et al. (1995) observed a minimum $\mathrm{Q}_{\mathrm{i}} / \mathrm{Q}_{\mathrm{o}}$ during the wet season of approximately 0.05 , whereas during the dry season $\mathrm{Q}_{\mathrm{i}} / \mathrm{Q}_{\mathrm{o}}$ values were higher than 0.2 . In the present study, $50 \%$ of the sampled points presented $\mathrm{Q}_{\mathrm{i}} / \mathrm{Q}_{0}$ values lower than 0.05 in the wet season, while more than $50 \%$ of the micro-sites presented $\mathrm{Q}_{\mathrm{i}} / \mathrm{Q}_{\mathrm{o}}$ values higher than 0.8 during the dry season. Local changes in light variables $\left(\mathrm{Q}_{\mathrm{i}}\right.$ and $\left.\mathrm{Q}_{\mathrm{i}} / \mathrm{Q}_{\mathrm{o}}\right)$ were statistically correlated between the dry and wet seasons, as well as in relation to the canopy cover variables, VSF and LAI in the dry season alone. These relationships suggest that, in spite of high canopy spatial heterogeneity, relative spatial stability of PPFD and $\mathrm{Q}_{\mathrm{i}} / \mathrm{Q}_{\mathrm{o}}$ occurs during both the dry and wet seasons, implying that on a small scale, brighter understory sites present higher levels of light during both the dry, as well as the wet, season.

Studies on tropical forests demonstrated that light conditions on the forest floor play an important role in the growth and survival of seedlings (Montgomery and Chazdon, 2002), species diversity (Schnitzer and Carson, 2001) and on seedling abundance and distribution (Nicotra et al., 1999). In situ studies on seedling growth and survival in Cerrado species are scarce. According to Franco (2005), although Cerrado woody species allocate a large proportion of their biomass to the roots during the initial growth period, water-stress during the dry season may have a major impact on seedling growth and during the wet season, canopy shading may be an important factor in photosynthesis. Nardoto et al. (1998) showed that the development of Kielmeyera coriacea seedlings was restricted by water-stress during the dry season, while during the wet season canopy shading potentially limited plant productivity. Similar results were obtained for Dalbergia miscolobium seedlings by Braz et al. (2000). However, Kanegae et al. (2000) concluded that seasonal drought was not an important mortality factor for Bowdichia virgilioides. Nevertheless, canopy shading, by reducing the photosynthetic photon flux density available to the understory, may be a major limiting factor in seedling growth.

It was observed that $72 \%$ of points sampled in the wet season presented PPFD values lower than $250 \mu \mathrm{mol} . \mathrm{m}^{-2} / \mathrm{s}$. By contrast, in the dry season, most $\mathrm{Q}_{\mathrm{i}}$ values varied from 1500 to $1817 \mu \mathrm{mol} . \mathrm{m}^{-2} / \mathrm{s}$, thereby propitiating high light availability in the understory. According to Prado and Moraes (1997), Cerrado woody species normally reach $90 \%$ of maximum $\mathrm{CO}_{2}$ assimilation rates $\left(\mathrm{A}_{\mathrm{CO} 2}\right)$, when PPFD values attain from 600 to $1200 \mu \mathrm{mol} . \mathrm{m}^{-2} / \mathrm{s}$. On considering these values and in most of the points sampled during the wet season, understory plants would not receive enough light for even $50 \%$ of their photosynthetic capacity around noon time. On the other hand, during the dry season, more than $50 \%$ of sampled points showed $\mathrm{Q}_{\mathrm{i}} / \mathrm{Q}_{\mathrm{o}}$ values of 0.8 to 1.0 , thus permitting light saturation for $\mathrm{CO}_{2}$ uptake. However, this apparent advantage may be relative, since, as pointed out by Franco (2005), during the dry season, water-stress may have a major impact on seedling growth and many seedlings may be leafless or partially defoliated.

Variability in understory light was higher during the dry than the wet season, this heterogeneity being related to canopy cover spatial complexity. Seasonal changes in canopies resulted in significant alteration in the light available for seedling growth. Nevertheless, the significance of this spatial and temporal environmental variability for seedling establishment and growth remains to be determined in order to explain the highly diversified flora of the Cerrado biome.

Acknowledgements - This study was developed with support from the ECMVS/UFMG programme, and we wish to thank the Fundação de Amparo à Pesquisa de Minas Gerais (FAPEMIG) for financial support. JPLF is grateful to the Brazilian Science Council (CNPq) for the fellowship awarded.

\section{References}

ASNER, GP., 1998. Biophysical and biochemical sources of variability in canopy reflectance. Remote Sensing of Environment, vol. 64, no. 3, p. 234-253.

BRAZ, VS., KANAGAE, MF. and FRANCO, AC., 2000. Estabelecimento e desenvolvimento de Dalbergia Miscolobium Benth. em duas fitofisionomias típicas dos cerrados do Brasil Central. Acta Botanica Brasilica, vol. 14, no. 3, p. 27-35.

BUCCI, SJ., GOLDSTEIN, G., MEIZER, FC., FRANCO, AC., CAMPANELLO, P. and SCHOLZ, FG., 2005. Mechanisms contributing to seasonal homeostasis of minimum leaf water potential and predawn disequilibrium between soil and plant water potential in Neotropical savanna trees. Trees, vol. 19, no. 3 , p. 296-304.

BUCCI, SJ., SCHOLZ, FG., GOLDSTEIN, G., HOFFMANN, WA., MEIZER, FC., FRANCO, AC., GIAMBELLUCA, T. and MIRALLES-WILHELM, F., 2008. Control on stand transpiration and soil water utilization along tree density gradient in a neotropical savanna. Agricultural and Forest Meteorology, vol. 148 , no. $6-7$, p. 839-849.

DUFRÊNE, E. and BRÉDA, N., 1995. Estimation of deciduous forest leaf area index using direct and indirect methods. Oecologia, vol. 104, no. 2, p. 156-162.

EITEN, G., 1972. The cerrado vegetation of Brazil. The Botanical Review, vol. 38, no. 2, p. 201-341.

FRANCO, AC., 2005. Biodiversidade de forma e função: implicações ecofisiológicas das estratégias de utilização de água, luz em plantas lenhosas do cerrado. In SCARIOT, A., SOUZA-SILVA, JC. and FELFILI, JM. (Orgs.). Cerrado: ecologia, biodiversidade e conservação. Brasília: Ministério do Meio Ambiente. p. 180-196.

GENDRON, F., MESSIEIR, C. and COMEAU, PG., 1998. Comparison of various methods for estimating the mean growing season percent photosynthetic photon flux density in forests. Agricultural and Forest Meteorology, vol. 92, no. 1, p. $55-70$.

GOWER, ST., KUCHARIK, CJ. and NORMAN, JM., 1999. Direct and indirect estimation of leaf area index, $f$ APAR, and net primary production of terrestrial ecosystems. Remote Sensing of Environment, vol. 70, no. 1, p. 29-51. 
HOFFMANN, WA., SILVA Jr., ER., MACHADO, GC., BUCCI, SJ., SCHOLZ, FG., GOLDSTEIN, G. and MEINZER, FC., 2005. Seasonal leaf dynamics across a tree density gradient in a Brazilian savanna. Oecologia, vol. 145, no. 2, p. 307-316.

HUTLEY, LB., O'GRADY, AP. and EAMUS, D., 2000. Evapotranspiration from Eucalypt open-forest savanna of Northern Australia. Funcional Ecology, vol. 14, no. 2, p. 183-194.

KANEGAE, MF., BRAZ, VDS. and FRANCO, AC. 2000. Efeitos da seca sazonal e disponibilidade de luz na sobrevivência e crescimento de Bowdichia virgilioides em duas fitofisionomias típicas dos cerrados do Brasil Central. Revista Brasileira de Botânica, vol. 23, no. 4, p. 459-468.

LÊ ROUX, X. and MORDELET, P., 1995. Leaf and canopy $\mathrm{CO}_{2}$ assimilation in a West African humid savanna during the early growing season. Journal of Tropical Ecology, vol. 11, no. 4, p. $529-545$.

MAASS, JM., VOSE, JM., SWANK, WT. and MARTÍNEZYRÍZAR, A., 1995. Seasonal changes of leaf area index (LAI) in tropical deciduous forests in west Mexico. Forest Ecology and Management, vol. 74, no. 1/3, p. 171-180.

MARQUES, AR., GARCIA, QS., RESENDE, JLP. and FERNANDES, GW., 2000. Variations in leaf characteristics of two species of Miconia in the Brazilian cerrado under different light intensities. Tropical Ecology, vol. 41, no. 1, p. 47-56.

MARTENS, SN., BRESHEARS, DD. and MEYER, CW., 2000. Spatial distribution of understory light along the grassland/forest continuum: effects of cover, height, and spatial patterns of tree canopies. Ecogical Modelling, vol. 126, no. 1, p. 79-93.

MIRANDA, AC., MIRANDA, HS., LLOYD, J., GRACE, J., FRANCEY, RJ., MCINTYRE, JA., MEIR, P., RIGGAN, P., LOCKWOOD, R. and BRASS, J., 1997. Fluxes of carbon, water and energy over Brazilian cerrado: an analysis using eddy covariance and stable isotopes. Plant, Cell and Environment, vol. 20 , no. 3, p. 315-328.

MONTGOMERY, RA. and CHAZDON, RL., 2002. Light gradient partitioning by tropical tree seedlings in the absence of canopy gaps. Oecologia, vol. 131, no. 2, p. 165-174.

PRADO, CHBA. and MORAES, JAPV., 1997. Photosynthetic capacity and specific leaf mass in twenty woody species of Cerrado vegetation under field conditions. Photosynthetica, vol. 33 , no. 1 , p. 103-112.
NARDOTO, GB., SOUZA, MP. and FRANCO, AC., 1998. Estabelecimento e padrões sazonais de produtividade de Kielmeyera coriaceae (Spr.) Mart. nos cerrados do Planalto Central: efeitos do estresse hídrico e sombreamento. Revista Brasileira de Botanica, vol. 21 no. 3, p. 313-319.

NICOTRA, AB., CHAZDON, RL. and IRIARTE, SVB., 1999. Spatial heterogeneity of light and woody seedling regeneration in tropical wet forests. Ecology, vol. 80, no. 6, p. 1908-1926.

O'GRADY, AP., CHEN, X., EAMUS, D. and HUTLEY, LB., 2000. Composition, leaf area index and standing biomass of eucalipt open forests near Darwin in the Northern Territory Australia. Australian Journal of Botany, vol. 48, no. 5, p. $629-638$

RATTER, JA., RIBEIRO, JF. and BRIDGEWATER, S., 1997. The Brazilian Cerrado vegetation and treats to its biodiversity. Annuals of Botany, vol. 80, no. 3, p. 223-230.

RATTER, JA., BRIDGEWATER, S. and RIBEIRO, JF., 2006. Biodiversity patterns of the woody vegetation of the Brazilian cerrado. In PENNINGTON, RT., LEWIS, GP. and RATTER, JA. (Eds.). Neotropical savannas and seasonally dry forests: plant diversity, biogeography and conservation. Boca Raton: CRC Press. p. 31-66.

SCHNITZER, SA. and CARSON, WP., 2001. Trefall gaps and the maintenance of species diversity in a tropical forest. Ecology, vol. 82, no. 4, p. 913-919.

SILVA Jr., ER., STERNBERG, L., HARIDASAN, M., HOFFMANN, WA., MIRALLES-WILHELM, F. and FRANCO, AC., 2008. Expansion of gallery forest into central Brazilian savannas. Global Change Biology, vol. 14, no. 9, p. $2108-2118$.

WELLES, JM. and NORMAN, JM., 1991. Instrument for indirect measurement of canopy architecture. Agronomy Journal, vol. 83, no. 5, p. 818-825.

WIRTH, R., WEBER, B. and RYEL, RJ., 2001. Spatial and temporal variability of canopy structure in a tropical moist forest. Acta Oecologica, vol. 22, no. 5/6, p. 235-244.

WHITE, MA., ASNER, GP., NEMANI, RR., PRIVETTE, JL. and RUNNING, SW., 2000. Measuring fractional cover and leaf area index in arid ecosystems: digital camera, radiation transmittance and laser altimetry methods. Remote Sening of Environment, vol. 74, no. 1, p. 45-57. 